INK AND TEARS 



\title{
INK AND TEARS
}

\author{
Memory, Mourning, and Writing \\ in the Yu Family
}

Rania Huntington

패

UNIVERSITY OF HAWAI'I PRESS

HONOLULU 
(C) 2018 University of Hawai'i Press

All rights reserved

Printed in the United States of America

$\begin{array}{llllllllllll}23 & 22 & 21 & 20 & 19 & 18 & 6 & 5 & 4 & 3 & 2 & 1\end{array}$

\section{Library of Congress Cataloging-in-Publication Data}

Names: Huntington, Rania, author.

Title: Ink and tears : memory, mourning, and writing in the Yu family / Rania Huntington.

Description: Honolulu : University of Hawai'i Press, [2018] | Includes bibliographical references and index.

Identifiers: LCCN 2018004209 | ISBN 9780824867096 (cloth : alk. paper)

Subjects: LCSH: Yu family. | Yu, Yue, 1821-1906. | Yu, Pingbo, 1900-1990. |

Authors, Chinese-Biography.

Classification: LCC PL2734.Z5 H86 2018 | DDC 895.18/4809—dc23

LC record available at https://lccn.loc.gov/2018004209

Cover art: Feng Zikai, Plum Tree and Railings, from Yu Pingbo, Yi (repr., Hangzhou, 2004), poem 14 .

University of Hawai'i Press books are printed on acid-free paper and meet the guidelines for permanence and durability of the Council on Library Resources. 
In memory of my father, Robert Watkinson Huntington III, 1937-2015 He took me to the library. 
